\title{
Toxicological effects induced by the biocide triclosan on Pseudokirchneriella subcapitata
}

\author{
Manuela D. Machado ${ }^{a, b, *}$, Eduardo V. Soares ${ }^{a, b, *}$ \\ ${ }^{a}$ Bioengineering Laboratory-CIETI, ISEP-School of Engineering, Polytechnic Institute of Porto, Rua Dr António Bernardino de Almeida, 431, 4249-015, Porto, Portugal \\ ${ }^{\mathrm{b}}$ CEB-Centre of Biological Engineering, University of Minho, Campus de Gualtar, 4710-057, Braga, Portugal
}

\section{A R T I C L E I N F O}

\section{Keywords:}

Cell size and shape

Oxidative stress

Antioxidant defenses

Photosynthesis

Metabolic activity

\begin{abstract}
A B S T R A C T
Triclosan, a widely used biocide broadly found in aquatic environments, is cause of concern due to its unknown effects on non-targets organisms. In this study, a multi biomarker approach was used in order to evaluate the 72 h-effect of triclosan on the freshwater alga Pseudokirchneriella subcapitata (Raphidocelis subcapitata). Triclosan, at environmental relevant concentrations (27 and $37 \mu \mathrm{g} \mathrm{L}^{-1}$ ), caused a decrease of proliferative capacity, which was accompanied by an increase of cell size and a profound alteration of algae shape. It was found that triclosan promoted the intracellular accumulation of reactive oxygen species, the depletion of non-enzymatic antioxidant defenses (reduced glutathione and carotenoids) and a decrease of cell metabolic activity. A reduction of photosynthetic pigments (chlorophyll $a$ and $b$ ) was also observed. For the highest concentration tested (37 $\mu \mathrm{g}$ $\mathrm{L}^{-1}$ ), a decrease of photosynthetic efficiency was detected along with a diminution of the relative transport rate of electrons on the photosynthetic chain. In conclusion, triclosan presents a deep impact on the microalga $P$. subcapitata morphology and physiology translated by multiple target sites instead of a specific point (cellular membrane) observed in the target organism (bacteria). Additionally, this study contributes to clarify the toxicity mechanisms of triclosan, in green algae, showing the existence of distinct modes of action of the biocide depending on the microalga.
\end{abstract}

\section{Introduction}

The industry of personal care products has been rising exponentially in the last decades. These products contain a series of compounds, like antibacterial agents, that are continuously arriving and accumulating in water bodies (Jennifer et al. 2017). Triclosan [TCS, 5-chloro-2-(2,4dichlorophenoxy) phenol] is a broad-spectrum antibacterial agent, with some antifungal and antiviral properties (Nag et al., 2018) acting as a biocide to control and/or kill organisms. TCS is a component of household and personal care products like soaps, detergents, toothpastes, deodorants, cosmetics, health and skincare products and also of textiles and plastic toys (Dhillon et al., 2015). It blocks the active site of the enzyme enoyl-acyl carrier protein reductase hindering the formation of bacterial fatty acids and preventing the proper formation of cell membranes which has as a consequence the stopping of bacterial growth (Dann and Hontela, 2011).

TCS is found in wastewaters and it is not completely eliminated in municipal treatment plants; therefore, it is one of the most frequently detected substances in aquatic environments (Bedoux et al., 2012). TCS has been found in ground, surface and also in drinking water, in a range of concentrations from $<0.2 \mathrm{ng} \mathrm{L}^{-1}$ to $40 \mu \mathrm{g} \mathrm{L} \mathrm{L}^{-1}$ (SCCS, 2010; Bedoux et al., 2012; Nag et al., 2018). Due to its hydrophobicity, TCS can accumulate in fat tissues and its presence in fish and humans has been described (Bedoux et al., 2012; Montaseri and Forbes, 2016). Consequently, in 2016, the United States Food and Drug Administration (US-FDA) prohibited TCS incorporation in household soaps; in the following year, US-FDA restricted its use in over-the-counter health care antiseptic products (US-FDA, 2017). In Europe, TCS has been banned from use in human hygiene products since 2017 (European Comission, 2016). The European Commission has also amended the EU cosmetics Regulation to restrict TCS concentration (max. 0.3\%) in products, including toothpastes, hand and body soaps (European Comission, 2014). Despite TCS had been extinct in consumer products, it continues to be used as an antibacterial agent in hospitals and other medical facilities and being found in water bodies all over the world with risks and unknown consequences for all ecosystem (Macri, 2017).

Owing to its antimicrobial properties and its presence in the environment, TCS is expected to have toxic effects on aquatic organisms. In

\footnotetext{
* Corresponding authors.

E-mail addresses: mmmachado@net.sapo.pt (M.D. Machado), evs@isep.ipp.pt (E.V. Soares).
} 
fact, toxic effects of TCS in fish (Liang et al., 2013; Paul et al., 2020), crustaceans (Rowett et al., 2016) and algae (Orvos et al., 2002; Yang et al., 2008; González-Pleiter et al., 2017; Machado and Soares, 2019) have been reported. Among aquatic organisms, algae present higher sensitivity to this biocide with $\mathrm{EC}_{50}$ values in the range of $\mu \mathrm{g} \mathrm{L}^{-1}$; contrasting with fish $\mathrm{LC}_{50}$ values of $\mathrm{mg} \mathrm{L}^{-1}$. Within the algae group, Pseudokirchneriella subcapitata presented $\mathrm{EC}_{50}$ values of the same order of concentration of those found in the environment, showing, in some cases, higher susceptibilities to TCS than bacteria (Orvos et al., 2002; Yang et al., 2008; Machado and Soares, 2019).

The toxicity bioassays with micro-algae, preconized by international organizations like the Organization for Economic Co-operation and development (OECD), United States Environmental Protection Agency (US-EPA) or International Organization for Standardization (ISO) use the algal growth inhibition as endpoint (OECD, 2011; ISO, 2012; US-EPA, 2012). This parameter provides a general information about the impact of a specific toxic on the algae population. More specific endpoints (physiological, biochemical and molecular) can provide more detailed information on the modes of action of the toxics in algal cells. In addition, these endpoints can later be used as warning signals of possible hazardous effects of aquatic contaminants on algae. In this context, the using of fluorochromes in the assessment of cell membrane integrity, general metabolic activity, intracellular level of reduced glutathione (GSH) or reactive oxygen species (ROS) constitutes a valuable tool (Machado and Soares, 2012a, b; 2013; 2016). Since algae are photosynthetic, the biochemical quantification of pigments (chlorophyll $a$ and b) (Soto et al., 2011; Machado and Soares, 2015), as well as the evaluation of photosynthetic efficiency, using pulse amplitude modulation (PAM) fluorometry (Kumar et al., 2014), are important biomarkers in the detection and characterization of the possible effects of toxicants on algae.

TCS toxicity studies with diverse algae (not including P. subcapitata) are reported (Ciniglia et al., 2005; Almeida et al., 2017; Xin et al., 2019a). This biocide promotes the reduction of chlorophyll concentration (Pan et al., 2018; Wang et al., 2020), perturbs photosynthesis (Ciniglia et al., 2005; Xin et al., 2019a) and increases membrane permeability (González-Pleiter et al., 2017; Wang et al., 2020). In addition to these effects, a reduction of algal biovolumes/size was reported for several spherical algae (Xin et al., 2017, 2019a, b). Due to its high sensitivity and the unawareness of the toxic effects promoted by this biocide on $P$. subcapitata, this alga appears as a good aquatic model organism, of lower trophic level, to be used in the elucidation of the TCS mechanisms of toxicity, on non-target organisms. Moreover, P. subcapitata (also commonly known as Raphidocelis subcapitata or Selenastrum capricornutum) has being recommended as standard microalga by US-EPA (2012) and OECD (OECD, 2011). Additionally, TCS effects on the environment and on non-target organisms, particularly at cellular level, have been poorly elucidated.

This study investigated, for the first time, the impact of TCS, at sublethal levels, on the alga $P$. subcapitata using a multi biomarker approach: algal biovolume, cell shape, membrane permeability, general metabolic activity, photosynthetic pigments content, photosynthetic efficiency, intracellular accumulation of ROS and level of cellular antioxidant defenses [GSH and carotenoids (CAR)]. This work presents new evidences regarding cellular responses of a photosynthetic non-target organism to TCS pollution.

\section{Material and methods}

\subsection{Alga and growing conditions}

The microalga Pseudokirchneriella subcapitata (strain 278/4) was obtained from Culture Collection of Algae and Protozoa (CCAP, UK), maintained in OECD medium (OECD, 2011) with $20 \mathrm{~g} \mathrm{~L}^{-1}$ agar and stored in the dark, at $4{ }^{\circ} \mathrm{C}$. Pre-cultures and cultures $\left(\sim 5 \times 10^{4}\right.$ cells $\mathrm{mL}^{-1}$ ) were prepared as previously described by Machado and Soares (2012a). For all experiments, algal cells with 2 days, in exponential phase of growth (with a doubling time of about $11 \mathrm{~h}$ ) were inoculated at $\sim 5 \times 10^{4}$ cells $\mathrm{mL}^{-1}$, on OECD medium and incubated at $25^{\circ} \mathrm{C}$, on an orbital shaker, at $100 \mathrm{rpm}$, under continuous light supplied by "cool white" fluorescent lamps (4300 K) with an intensity of $4000 \mathrm{~lx}$ at the flasks surface, as previously described (Machado and Soares, 2012a).

\subsection{Toxicity assays}

Pseudokirchneriella subcapitata, in exponential phase of growth, at 5 $\times 10^{4}$ cells $\mathrm{mL}^{-1}$, was exposed in OECD medium to 27 or $37 \mu \mathrm{g} \mathrm{L}^{-1} \mathrm{TCS}$ in Erlenmeyer flasks $(1 \mathrm{~L}$ ) with a final volume of $400 \mathrm{~mL}$ and incubated as described above. These nominal TCS concentrations correspond to an algal growth inhibition of 50 and $90 \%$, when compared with control, respectively, after an exposure of $72 \mathrm{~h}$. TCS values were previously determined by Machado and Soares (2019) using the growth inhibition test (OECD, 2011). The TCS concentration corresponding to $72 \mathrm{~h}-\mathrm{EC}_{50}$ was selected since this EC value is commonly used, for comparative purposes, as a measure of toxicity; $72 \mathrm{~h}-\mathrm{EC}_{90}\left(37 \mu \mathrm{g} \mathrm{L}^{-1}\right)$ was chosen with the aim to study the effect of the biocide at a concentration that can strongly impact algal cells.

TCS (purity $\geq 97 \%$, ref. 72779) was purchased from Sigma-Aldrich. TCS stock solution (1000 $\mathrm{mg} \mathrm{L}^{-1}$ ) was prepared in dimethyl sulfoxide (DMSO, Sigma-Aldrich). Toxicity assays presented a DMSO concentration $\leq 0.004 \%(\mathrm{v} / \mathrm{v})$; control experiments demonstrated that, at this concentration, DMSO did not affect $P$. subcapitata growth (Machado and Soares, 2019).

As recommended by OECD for growth inhibition tests, an incubation time of $72 \mathrm{~h}$ was used in toxicity assays to assure at least a 16 -fold growth in control. Then, cells were harvested by centrifugation $(2500$ $\mathrm{x} g, 5 \mathrm{~min}$ ) and resuspended in $100 \mathrm{mmol} \mathrm{L}^{-1}$ phosphate-buffered saline (PBS), at $\mathrm{pH} 7.0$, for quantification of ROS production or in OECD medium for the remaining determinations.

Cell concentration was determined, in quintuplicate, using an automatic cell counter (TC10, Bio-Rad).

\subsection{Algae biovolume}

Photos of cells were randomly acquired using a phase-contrast microscope, with a N plan X 100 objective, equipped with a Leica DC $300 \mathrm{~F}$ camera and processed using Leica IM 50-Image manager software. Biovolume was calculated as previously described (Machado and Soares, 2014). The experiment was repeated, independently, three times. In each experiment and for each TCS concentration, at least 300 cells were examined; thus, for each TCS concentration, a total of $\geq 900$ cells were analyzed.

\subsection{ROS production}

Intracellular ROS accumulation was evaluated with the probe 2',7'-dichlorodihydrofluorescein diacetate ( $\left.\mathrm{H}_{2} \mathrm{DCFDA}\right)$. Once inside the cells, $\mathrm{H}_{2}$ DCFDA is enzymatically deacetylated to $\mathrm{H}_{2} \mathrm{DCF}$, which can be readily oxidized (by several types of ROS) to the fluorescent product 2',7'-dichlorofluorescein (DCF) (Tarpey et al., 2004).

After treatment, algal cells $\left(1 \times 10^{6} \mathrm{~mL}^{-1}\right)$ were resuspended in 100 mmol L ${ }^{-1}$ PBS (pH 7.0) and incubated with $10 \mu \mathrm{mol} \mathrm{L}^{-1} \mathrm{H}_{2} \mathrm{DCFDA}$ (Sigma-Aldrich), for $90 \mathrm{~min}$, in the dark, as detailed by Machado and Soares (2016). Fluorescence intensity was quantified, in quintuplicate, in a microplate reader, as relative fluorescence units (RFUs), at a fluorescence excitation wavelength of $485 / 14 \mathrm{~nm}$ and an emission of $535 / 25 \mathrm{~nm}$. Fluorescence results were corrected by subtracting cell, medium (where cells were suspended) and dye autofluorescence and normalized considering the algal biovolume. The results are expressed as the ratio of fluorescence of the assay/fluorescence of the control. 


\subsection{GSH content}

Intracellular reduced glutathione (GSH) content of algal cells was estimated with monochlorobimane $(\mathrm{mBCl})$. This probe readily enters cells to form fluorescent bimane-glutathione (B-SG) adducts that can be measured fluorometrically (Machado and Soares, 2012b).

Algal cells $\left(1 \times 10^{6} \mathrm{~mL}^{-1}\right)$, in OECD medium, were stained with 50 $\mu \mathrm{mol} \mathrm{L}{ }^{-1} \mathrm{mBCl}$ (Sigma-Aldrich), for $90 \mathrm{~min}$, in the dark, as described by Machado and Soares (2012b). As negative control, cells were exposed to $1 \mathrm{mmol} \mathrm{L}^{-1}$ iodoacetamide (Sigma-Aldrich), during $1 \mathrm{~h}$, before staining. Fluorescence intensity was determined in quintuplicate, in a microplate reader, at fluorescence excitation of $355 / 40 \mathrm{~nm}$ and an emission of $460 / 25 \mathrm{~nm}$. Fluorescence was corrected and normalized and the results are expressed as described above (section 2.4).

\subsection{Cell membrane permeability}

Cells with a plasma-membrane permeabilized were discriminated using the membrane-impermeant SYTOX Green (SG) probe, as previously described (Machado and Soares, 2012a). SG enters only in cells with compromised membrane and binds to DNA, exhibiting a green fluorescence (Haugland, 2005).

Cells $\left(1 \times 10^{6} \mathrm{~mL}^{-1}\right)$ were incubated with $0.5 \mu \mathrm{mol} \mathrm{L}{ }^{-1}$ SG (Molecular Probes, Invitrogen), in the dark, at room temperature, for 20 min. Positive (cells with permeabilized membrane by heat treatment, at $65^{\circ} \mathrm{C}$, for $1 \mathrm{~h}$ ) and negative control (cells not exposed to TCS) were used. Cells were observed with an epifluorescence microscope, equipped with an HBO-100 mercury lamp and a GFP filter from Leica. The experiment was repeated, independently, three times. In each experiment and for each TCS concentration, at least 400 cells were examined; therefore, for each TCS concentration, a total of $\geq 1200$ cells were analyzed in randomly selected microscope fields.

\subsection{Esterase activity}

TCS inhibits the activity of the enzyme FabI in bacteria (McMurray et al. 1998, Levy et al. 1999). One possibility is that TCS can also affect other enzymes in non-target organisms, namely esterases, which are known to be involved in cellular detoxification mechanisms (Fukami and Yokoi, 2012). Esterase activity, which reflects general metabolic activity (Regel et al., 2002), was determined using the fluorescein diacetate (FDA) hydrolysis assay, described by Machado and Soares (2013). The activity of these enzymes results in the hydrolytic cleavage of FDA (nonfluorescent) into fluorescein (green-fluorescent) that can be measured fluorometrically (Jochem, 2000; Machado and Soares, 2013).

Algae $\left(5 \times 10^{5}\right.$ cells $\left.\mathrm{mL}^{-1}\right)$ were incubated with $20 \mu \mathrm{mol} \mathrm{L}^{-1}$ FDA (Sigma-Aldrich), in the dark, at $25{ }^{\circ} \mathrm{C}$, for $40 \mathrm{~min}$. Positive (cells not exposed to TCS) and negative controls (heat treated cells at $65{ }^{\circ} \mathrm{C}$, for 1 h) were also included. Samples fluorescence was measured in quintuplicate, corrected and normalized and the results expressed as described above (section 2.4).

\subsection{Chlorophyll (Chl) $a, b$ and carotenoids}

Pigments from algal cells $\left(3 \times 10^{6} \mathrm{~mL}^{-1}\right)$ were extracted with $90 \%$ acetone (v/v) (VWR Chemicals), at $4{ }^{\circ} \mathrm{C}$, for $20 \mathrm{~h}$. Then, samples were centrifuged (2500 x $\mathrm{g}, 10 \mathrm{~min}$ ) and pigments were determined from supernatant. Chlorophylls content were determined, spectrophotometrically, by the measurement of the absorbance at 630, 647, 664 and $691 \mathrm{~nm}$, as previously described by Soto et al. (2011). CAR were determined at $480 \mathrm{~nm}$, as described by Strickland and Parsons (1972). Pigments content, determined in triplicate, was normalized by algal biovolume and expressed as the ratio of pigment content in the assay and the pigment content in the control.

\subsection{Photosynthetic performance}

Photosynthetic performance of Photosystem II (PSII) of $P$. subcapitata, a good stress indicator, was evaluated by PAM fluorometry using a Junior PAM-fluorometer (Walz, Germany) as described by Machado and Soares (2020). PSII is the first complex protein that executes the initial reaction of photosynthesis. Firstly, the minimal fluorescence $\left(\mathrm{F}_{0}\right)$ of 30 min-dark adapted algal cells $\left(3 \times 10^{6} \mathrm{~mL}^{-1}\right)$ was measured. Subsequently, the maximum fluorescence $\left(\mathrm{F}_{\mathrm{m}}\right)$ yield was quantified allowing the calculation of the maximum photochemical quantum yield of PSII $\left(\mathrm{F}_{\mathrm{v}} / \mathrm{F}_{\mathrm{m}}\right)$ by the WinControl software (version 3.2.2). Fv/Fm allows to determine the capacity of algal cell to convert light into chemical energy.

Then, a saturated pulse $\left(190 \mu \mathrm{mol} \mathrm{m} \mathrm{m}^{-2} \mathrm{~s}^{-1}\right)$ was applied on algal cells and the minimum and the maximum fluorescence in the light ( $\mathrm{F}_{0}{ }_{0}$ and $\mathrm{F}_{\mathrm{m}}$, respectively) were determined. These parameters (tenfold measured) were then used on the calculation of the effective photochemical quantum yield of PSII $\left(\phi_{\mathrm{PSII}}\right)$, the relative electron transport rate (ETR) and the non-photochemical quenching (NPQ) by the WinControl software. $\phi_{\mathrm{PSII}}$ measures the proportion of the light absorbed by chlorophyll associated to PSII that is used in photochemistry; ETR represents the rate of electron transport through the PSII and NPQ depends on the safe dissipation of absorbed light energy as heat from PSII (Maxwell and Johnson, 2000). Chlorophyll performance parameters allow to evaluate the efficiency of light energy utilization and detect effects on chloroplast function (Murchie and Lawson, 2013).

Photosynthetic performance of the alga $P$. subcapitata was expressed, for each parameter, as the ratio between value in the assay and the value in the control.

\subsection{Data analysis}

Results are presented as the mean \pm standard deviation (SD) and outcome from three independent experiments. Statistical analyses were performed comparing the difference between control and cells exposed to each TCS concentration, using unpaired $t$ test; $P$ values $<0.05$ were considered statistically significant.

\section{Results}

The knowledge of the adverse effects of biocides on algal species is crucial to understand the risks of these compounds in the aquatic environment. With this goal, the detrimental impact of the biocide TCS on a non-target organism, the freshwater microalga $P$. subcapitata, was evaluated using a multiple endpoint approach.

\subsection{Growth, biovolume and shape}

The exposure of the freshwater alga $P$. subcapitata to 27 and $37 \mu \mathrm{g}$ $\mathrm{L}^{-1}$ of TCS, for $72 \mathrm{~h}$, led to a significant loss of proliferative capacity, when compared to control; at these TCS concentrations, algal growth (yield) was reduced $59 \pm 3 \%$ and $88 \pm 1 \%$, respectively (Fig. 1A).

An alteration of cell size was observed in algae incubated with TCS. The increase of TCS concentration originated an enlargement of algal size (Fig. 1B). Control cells had an average biovolume of $22 \mu \mathrm{m}^{3}$, while cells exposed to 27 and $37 \mu \mathrm{L} \mathrm{L}^{-1}$ TCS exhibited mean values of 36 and $120 \mu^{3}$, respectively (Fig. 1B). Furthermore, a large heterogeneity of algal biovolume was observed with the increase of TCS concentration, as denoted by the size of the error bars. In control, $\sim 98 \%$ of cells had a biovolume $<50 \mu \mathrm{m}^{3}$ (Figure S1 of Supplementary Material), while in algae exposed to $27 \mu \mathrm{g} \mathrm{L}^{-1} \mathrm{TCS}, 81 \%$ had a biovolume $<50 \mu \mathrm{m}^{3}, 13 \%$ presented a volume between 50 and $100 \mu \mathrm{m}^{3}$ and $6 \%$ showed $\geq 100$ $\mu \mathrm{m}^{3}$. An extended biovolume distribution for algae incubated with $37 \mu \mathrm{g}$ $\mathrm{L}^{-1} \mathrm{TCS}$, for $72 \mathrm{~h}$, was observed; thus, $12-24 \%$ of cells in all defined biovolume classes were observed. Particularly remarkable is the presence of $\sim 20 \%$ of cells with a biovolume $\geq 200 \mu \mathrm{m}^{3}$ (Figure S1 of 
A

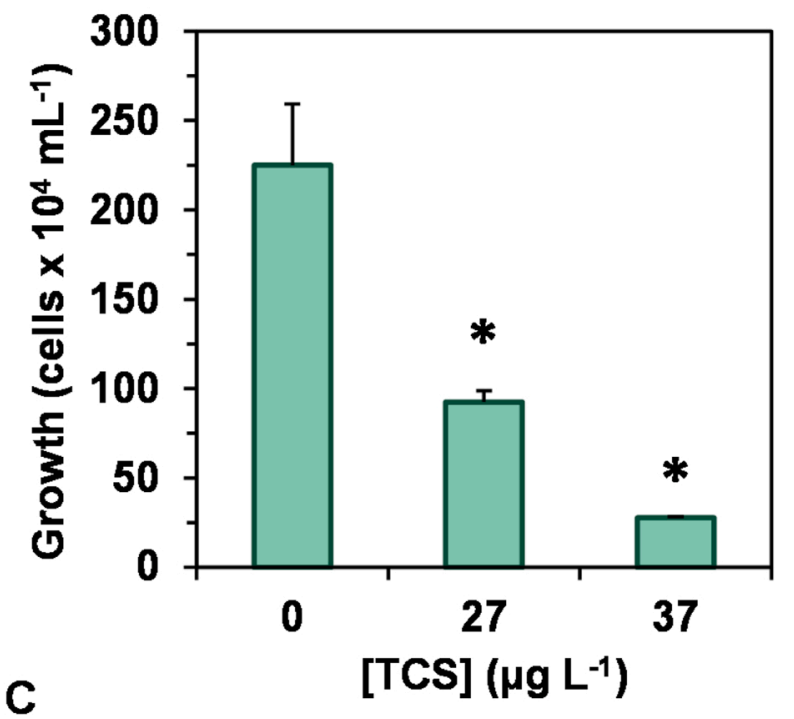

B

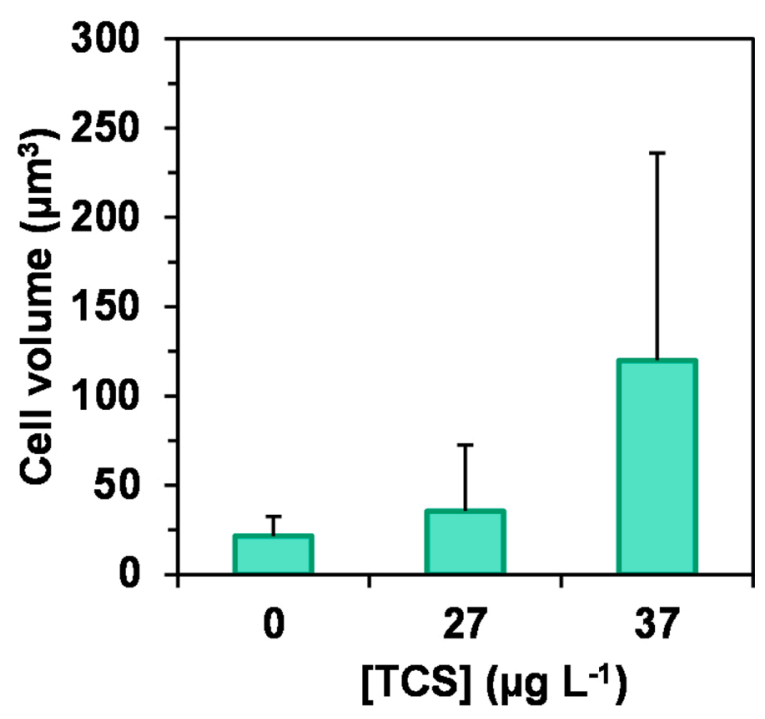

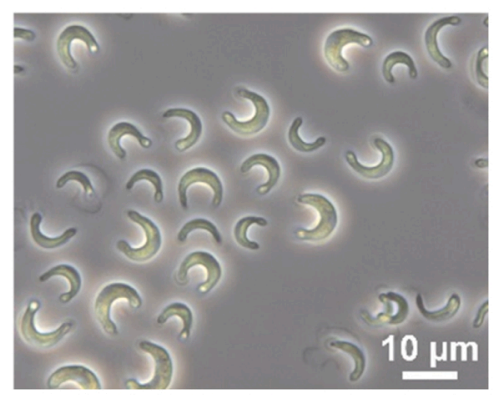

0

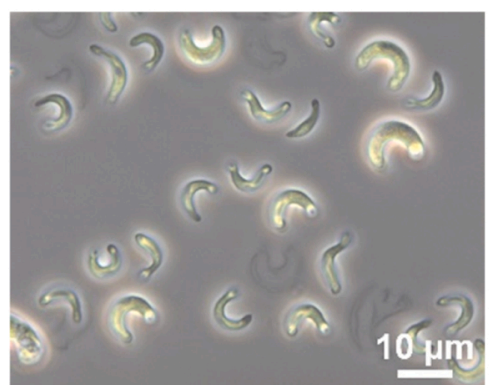

27

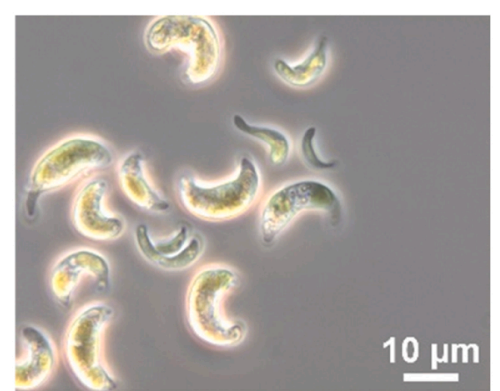

37

[TCS] $\mu \mathrm{g} \mathrm{L}^{-1}$

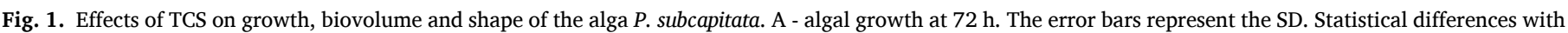

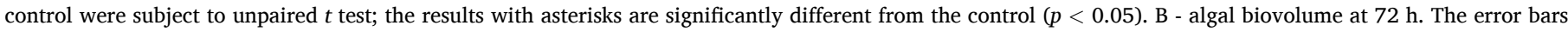
represent the SD. C- Phase contrast photomicrographs of algal cells at $72 \mathrm{~h}$.

\section{Supplementary Material).}

Accompanying the increase of cell biovolume, a modification of the typical sickle-like morphology of $P$. subcapitata, when incubated with TCS, was found. Accordingly, in the algal population incubated with 37 $\mu \mathrm{g} \mathrm{L}{ }^{-1} \mathrm{TCS}$, for $72 \mathrm{~h}$, cells with an increased biovolume, but maintaining their original shape, as well as cells very deformed or, practically, without a defined shape (aberrant morphology) were observed (Figure S2B of Supplementary Material; arrows 2 and 3, respectively).

\subsection{Intracellular ROS accumulation and non-enzymatic antioxidant defenses}

The generation of ROS with the alteration of redox status is a common event in algae in response to organic and inorganic toxicants (Mallick and Mohn, 2000). With the aim to evaluate if TCS induces oxidative stress in P. subcapitata, the intracellular accumulation of ROS was monitored using $\mathrm{H}_{2}$ DCFDA (Chen et al., 2010). Algal cells exposed to 27 or $37 \mu \mathrm{g} \mathrm{L}^{-1} \mathrm{TCS}$, for $72 \mathrm{~h}$, exhibited a significant increase of intracellular ROS levels, comparatively to the control (Fig. 2A).

GSH and CAR are important compounds involved in the defense against oxidative stress (Pinto et al., 2003). Taking into account that the biocide induced an intracellular accumulation of ROS, it was evaluated the level of the non-enzymatic defenses GSH and CAR in the algae exposed to TCS. It was observed that algae incubated with 27 or $37 \mu \mathrm{g}$ L-1 TCS, for $72 \mathrm{~h}$, presented a reduced level of GSH (Fig. 2B) and CAR
(Fig. 2C). The generation of ROS combined with the depletion of cellular antioxidant defenses suggests that exposure to TCS induced an alteration in the redox state of algae.

\subsection{Cell membrane permeability}

Having in consideration that TCS increased intracellular ROS levels and that ROS interact with biological membranes promoting a variety of functional changes (Stark, 2005), the impact of this biocide on alga cell membrane permeability was evaluated using the SYTOX Green probe (Machado and Soares, 2012a). It was observed that about 6 and 13\% of the algae population, incubated with 27 or $37 \mu \mathrm{g} \mathrm{L}{ }^{-1} \mathrm{TCS}$, for $72 \mathrm{~h}$, respectively, presented the plasma membrane permeable to SG (Fig. 3). This result indicates that, even when exposed to a high TCS concentration $\left(37 \mu \mathrm{g} \mathrm{L}{ }^{-1}\right)$, the algae retained, mostly, the integrity of the plasma membrane.

\subsection{Metabolic activity}

In this study, it was observed that TCS provoked a significant inhibition of the esterasic activity, in a concentration-dependent way. Algal cells exposed to 27 or $37 \mu \mathrm{g} \mathrm{L}{ }^{-1}$ TCS presented a reduction of $38 \%$ and $72 \%$ of the metabolic activity, respectively, when compared to control cells (Fig. 4). 
A
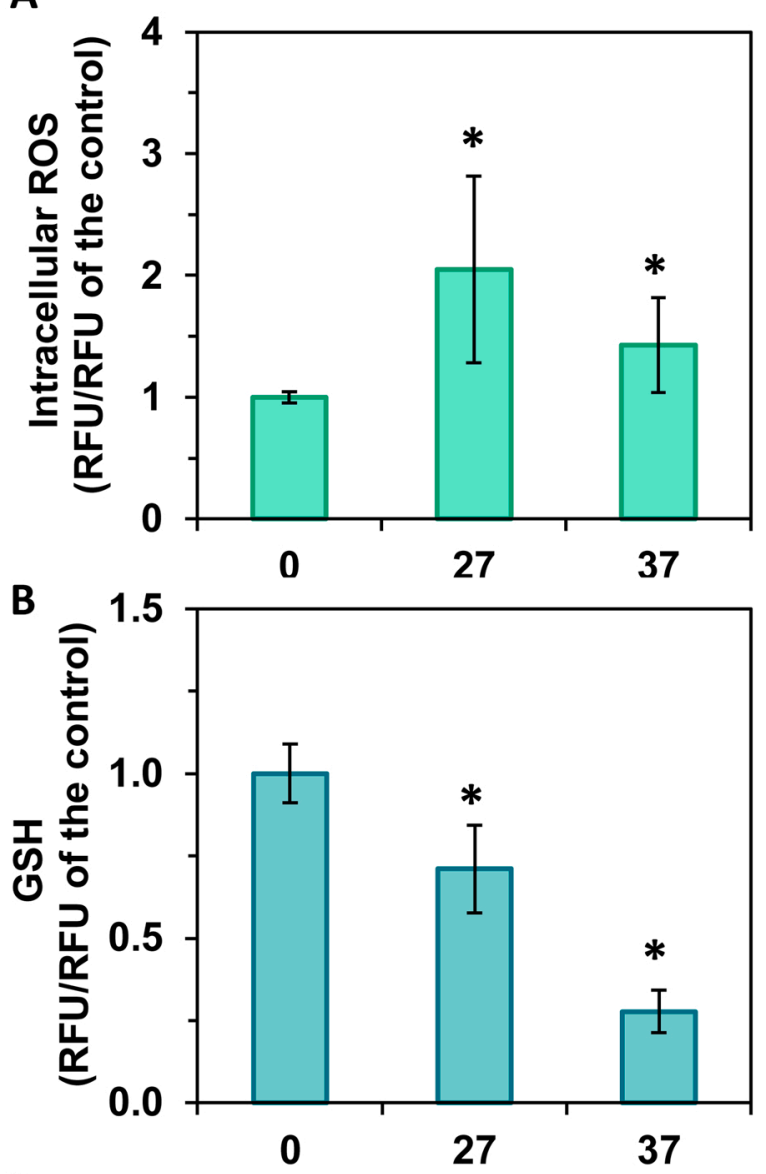

C

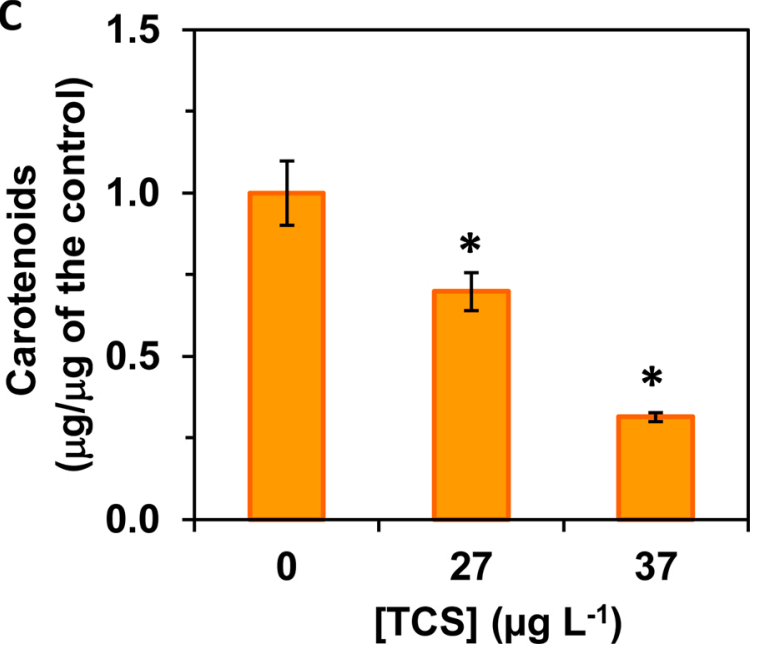

Fig. 2. Redox status of $P$. subcapitata algal cells exposed to TCS, for $72 \mathrm{~h}$. A intracellular ROS generation. B - reduced glutathione (GSH) content. C - carotenoids (CAR) content. The error bars represent the SD. Statistical differences with control were subject to unpaired $t$ test; the results with asterisks are significantly different from the control $(p<0.05)$.

\subsection{Chlorophyll pigments and photosynthetic efficiency}

Algae depend of photosynthesis to obtain energy and grow. In this context, it was evaluated the possible perturbations induced by TCS on algae photosynthetic activity through the quantification of photosynthetic pigments and the assessment of photosynthetic efficiency.

TCS provoked a significant decay $(p<0.05)$ of photosynthetic pigments in the alga $P$. subcapitata. The exposure to $27 \mu \mathrm{g} \mathrm{L}^{-1} \mathrm{TCS}$ induced a

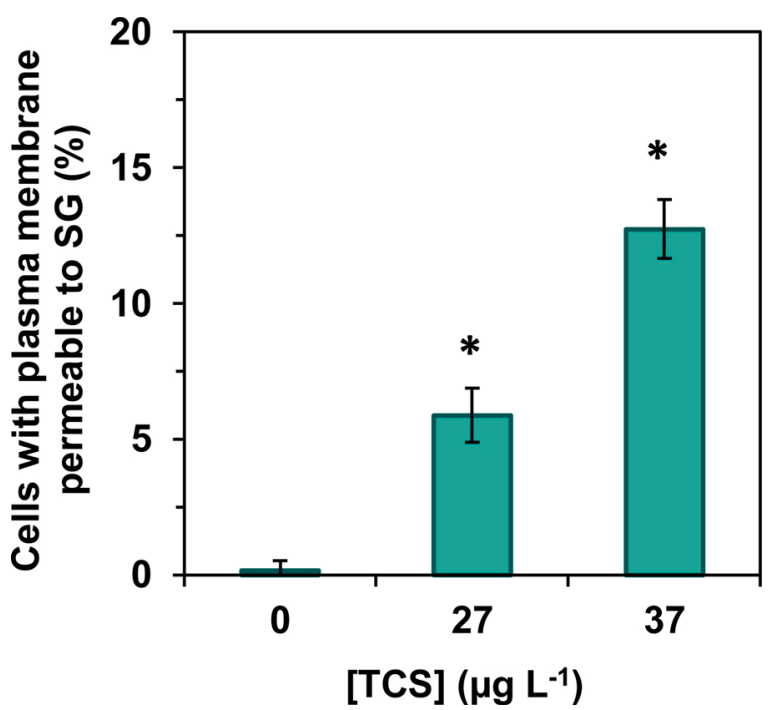

Fig. 3. Impact of TCS on cell membrane permeability of $P$. subcapitata. After treatment for $72 \mathrm{~h}$, cells were incubated with the cell membrane-impermeant SYTOX Green (SG) and the \% of cells permeable to the dye was determined. The error bars represent the SD. Statistical differences with control were subject to unpaired $t$ test; the results with asterisks are significantly different from the control $(p<0.05)$.

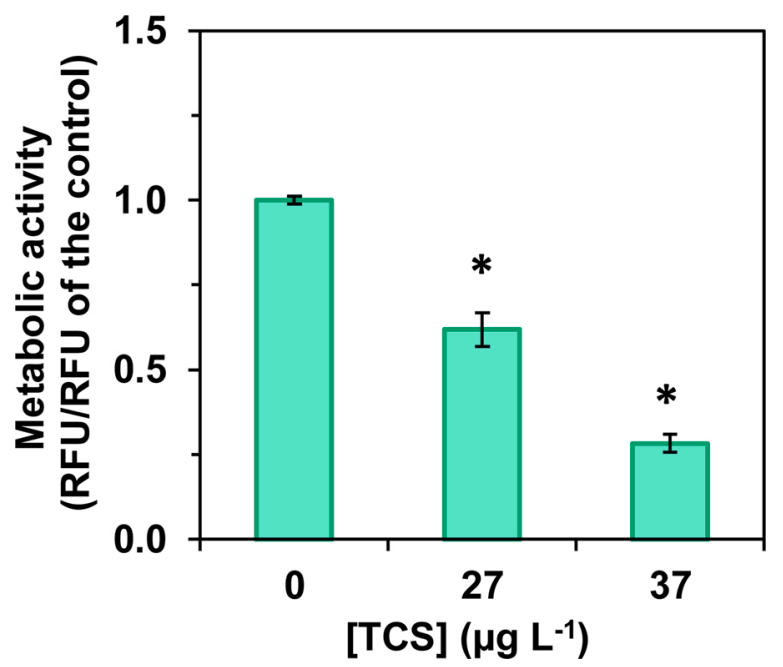

Fig. 4. General metabolic activity of the alga $P$. subcapitata exposed to TCS, for $72 \mathrm{~h}$. Metabolic activity was assessed using the fluorescein diacetate hydrolysis assay. The error bars represent the SD. Statistical differences with control were subject to unpaired $t$ test; the results with asterisks are significantly different from the control $(p<0.05)$.

reduction of $25 \%$ of chl $a$ (Fig. 5A) and $29 \%$ of chl $b$ (Fig. 5B). The hardest damages were observed for $37 \mu \mathrm{g} \mathrm{L^{-1 }}$ TCS, which caused a depreciation of $74 \%$ of chl $a$ and chl $b$.

A disturbance of photosynthesis was observed in algae exposed to 37 $\mu \mathrm{g} \mathrm{L}^{-1}$ TCS. For this TCS concentration a significant reduction of the maximum photochemical quantum yield of PSII $\left(F_{v} / F_{m}\right)$ (Fig. $\left.5 \mathrm{C}\right)$, the effective photochemical quantum yield of PSII ( $\left.\phi_{\text {PSII }}\right)$ (Fig. 5D) and the relative electron transport rate (ETR) was detected (Fig. 5E), which indicate a reduction of the energy used in photosynthesis. A soft tendency for an increase of the non-photochemical quenching was observed for 27 and $37 \mu \mathrm{L} \mathrm{L}^{-1}$ TCS (Fig. 5F), suggesting that algal cells were attempting to dissipate thermally the excess of energy non-channeled for photosynthesis. 
A

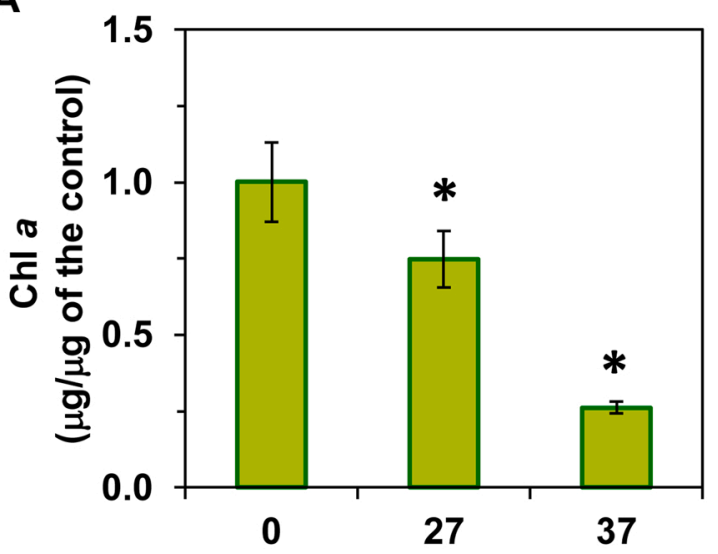

C

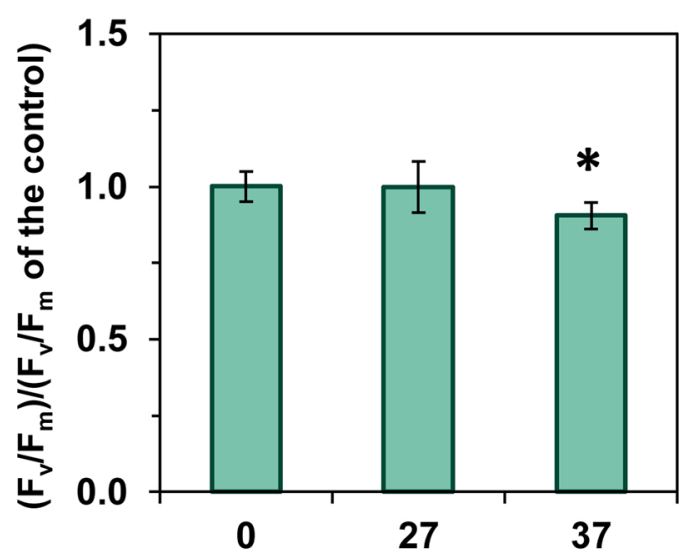

E

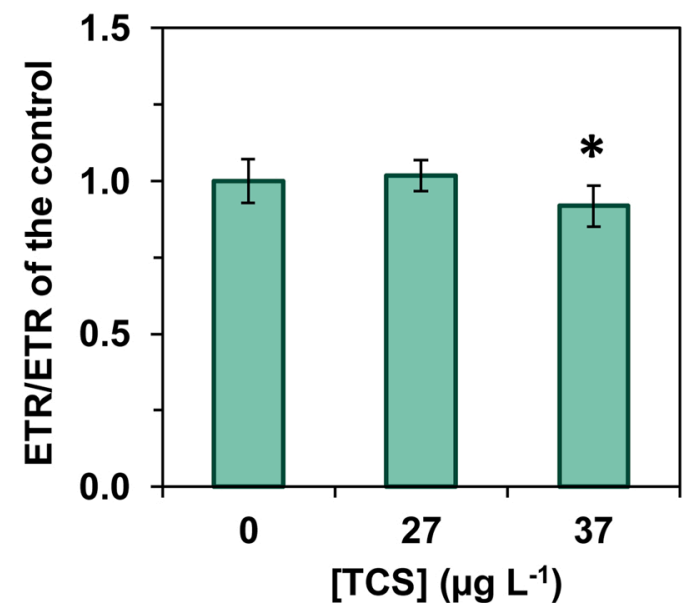

B

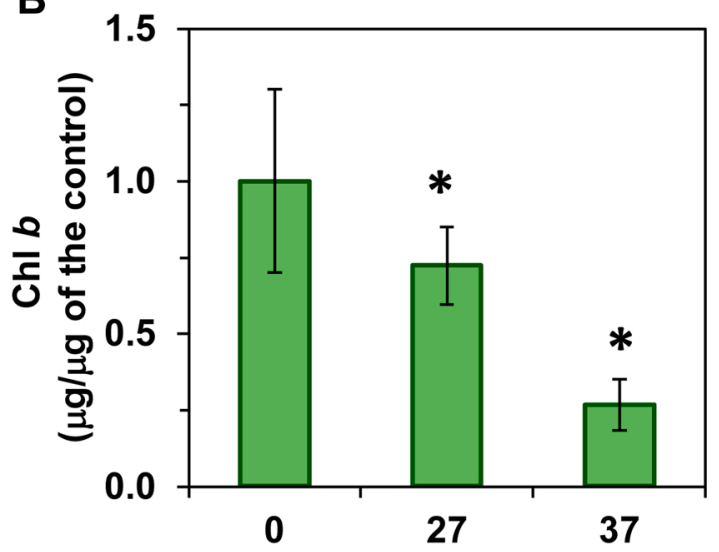

D

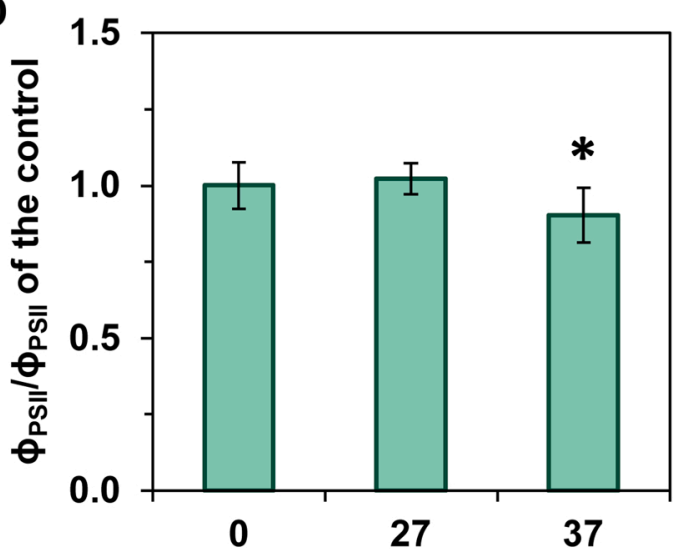

$\mathbf{F}$

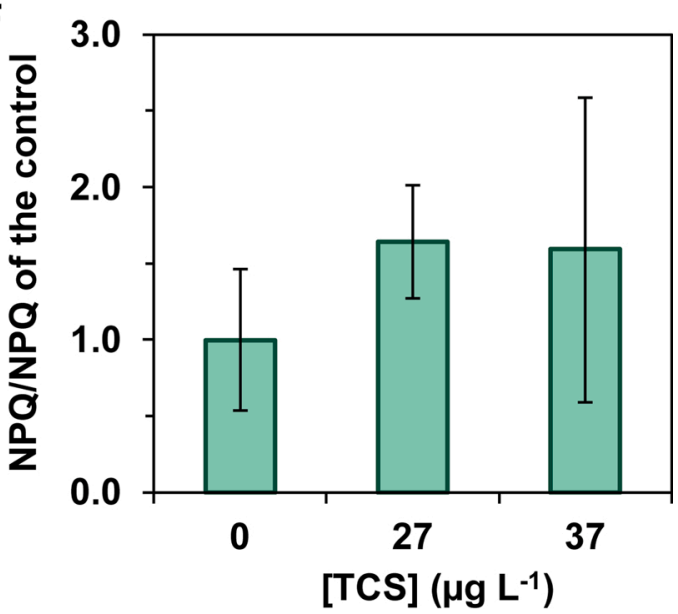

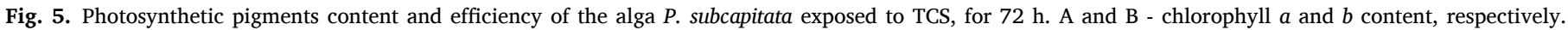

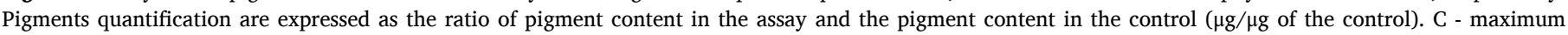

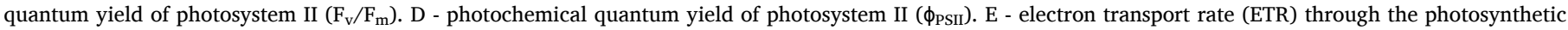

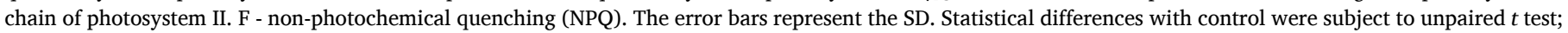
the results with asterisks are significantly different from the control $(p<0.05)$.

\section{Discussion}

TCS is incorporated in different products to combat pathogenic bacteria. Due to its wide use and inefficient removal from wastewaters, by conventional treatment processes, TCS is found in aquatic environment where it can pose an undesirable effect on non-target organisms.

This biocide, at environmental relevant concentrations (27 or $37 \mu \mathrm{g}$ $\mathrm{L}^{-1}$ ), induced in the microalgae $P$. subcapitata the loss of cell proliferation (Fig. 1A) and metabolic activity (Fig. 4) and the increase of cell biovolume (Fig. 1B, C). A progressive inhibition of growth, with increasing TCS concentrations was also described in the algae Chlamydomonas reinhardtii, Chlorococcum sp. and Asterococcus superbus (Pan et al., 2018; Xin et al., 2019a; Wang et al., 2020), at higher concentrations than those here observed with $P$. subcapitata. TCS also promoted an inhibition of esterase activity in $C$. reinhardtii (González-Pleiter et al., 2017). However, contrary to what it was here observed with $P$. subcapitata, TCS had little effect on the size of $C$. reinhardtii (Xin et al. 2019a) or promoted a decrease in the size of Asterococcus viridis, 
Chlorococcum sp., Closterium ehrenbergii and Eremosphaera viridis (Ciniglia et al., 2005; Xin et al., 2019a, b). The different impact of TCS on algae size suggests that distinct mechanisms should underlie the toxicity of this biocide in green algae.

The exposure of $P$. subcapitata to TCS also induced a reduction of the photosynthetic pigments chl $a$ and $b$ and photosynthetic activity; the last effect was observed for the highest TCS concentration tested $\left(37 \mu \mathrm{g} \mathrm{L}^{-1}\right)$ (Fig. 5). It is described that algal cells, as a compensatory mechanism, increase photosynthetic pigments biosynthesis/concentration when the light is used less efficiently due to partial inhibition of photosynthesis (Beale and Appleman, 1971). In the present work, a reduction of chl $a$ and $b$ concentration was observed (Fig. 5A, B) for $27 \mu \mathrm{g} \mathrm{L}^{-1} \mathrm{TCS}$, when algae exhibited a photosynthetic activity similar to the control, evaluated through the maximum quantum yield $\left(F_{\mathrm{v}} / F_{\mathrm{m}}\right)$ and effective PSII quantum yield ( $\varphi_{\text {PSII }}$ ) (Fig. 5C, D). The decrease of chlorophyll content can be to their degradation and/or biosynthesis inhibition, as consequence of the reduction of the metabolic activity (Fig. 4); the last mechanism (biosynthesis inhibition) seems to be more plausible, taking into account the complexity of the chlorophyll biosynthesis pathway which involve more than 15 enzymatic reactions (Gálová et al., 2008). Similar effects were described in other microalgae exposed to TCS, namely a decrease of chlorophyll concentration on C. reinhardtii and Chlorococcum sp. (Pan et al., 2018; Xin et al., 2019a) and a reduction of photosynthetic activity on Scenedesmus vacuolatus, Nitzschia palea (Franz et al., 2008) and C. ehrenbergii (Ciniglia et al., 2005); in the last alga, a modification of chloroplast morphology and dimension was also observed. The green alga $E$. viridis after an exposure for $120 \mathrm{~h}$ to $1 \mathrm{mg}$ $\mathrm{L}^{-1}$ TCS also presented alterations on chloroplast, namely membrane disappearance and scarce thylakoids (Xin et al., 2019b).

TCS induced oxidative stress in the algal cells of $P$. subcapitata, translated by an increase of intracellular ROS production (Fig. 2A) and a decline of non-enzymatic antioxidant defenses (GSH and CAR) content (Fig. 2B, C). Like in the case of photosynthetic pigments, the decrease of GSH and CAR can be due to the inhibition of their biosynthesis or to their consumption in an attempt of algae to reduce ROS to physiological levels. Compatible with our results it was described an extensive formation of ROS, induced by TCS, in C. reinhardtii and E. viridis (González-Pleiter et al., 2017; Xin et al., 2019b; Wang et al., 2020) and the downregulation of the expression of several antioxidant genes in C. reinhardtii (González-Pleiter et al., 2017).

ROS production in photosynthetic eukaryotic organisms, including algal cells, can have origin in different organelles such as peroxisomes and endoplasmic reticulum, associated with fatty acid $\beta$-oxidation or the activity of cytochrome P-450 in several detoxification processes; in addition, ROS can be generated in mitochondria and chloroplasts, as a consequence of the leakage of electrons from the electron transport chains present in the inner mitochondrial or thylakoid membranes, respectively (Mittler et al., 2004; Lesser, 2006; Del Río and López-Huertas, 2016). Although chloroplasts can participate in ROS production, at high TCS concentration $\left(37 \mu \mathrm{g} \mathrm{L}^{-1}\right)$, due to the limitation of electron transport in PSII (Fig. 5E), this should not be the main mechanism of ROS formation in P. subcapitata, exposed to TCS, since it was observed the increase of intracellular accumulation of ROS in algal cells exposed to $27 \mu \mathrm{g} \mathrm{L}^{-1} \mathrm{TCS}$, without modification of photosynthetic efficiency (Fig. 5C, D) or alteration of ETR (Fig. 5E).

In most bacteria, plants and algae, fatty acid biosynthesis is catalyzed by a group of enzymes known as the type II fatty acid synthase (FASII) system (Zheng et al., 2013). In the FASII system, enoyl-acyl carrier protein reductase has a crucial role for terminating fatty acid elongation (Zheng et al., 2013). It is known that in bacteria, TCS block lipid synthesis through the inhibition of the enzyme enoyl-acyl carrier protein reductase (FabI), causing the destabilization of cell membrane and ultimately the loss of barrier functions (Phan and Marquis, 2006). Although this enzyme can be also found in microalgae, namely on P. subcapitata (Suzuki et al., 2018), and therefore be inhibited by TCS, cell membrane seems not to be the primary target of the action of this biocide. Compatible with this possibility it was observed that more than 94 and $87 \%$ of cell population retained the integrity of plasma membrane when exposed during $72 \mathrm{~h}$ to 27 or $37 \mu \mathrm{g} \mathrm{L}{ }^{-1} \mathrm{TCS}$, respectively (Fig. 3). A different outcome was reported for the microalga C. reinhardtii where the exposure to TCS, for $24 \mathrm{~h}$, induced the cell membrane damage of almost $90 \%$ of the population due to ROS formation and lipid peroxidation (González-Pleiter et al., 2017).

\section{Conclusion}

Pseudokirchneriella subcapitata morphology and physiology was severely impacted due to the exposure for $72 \mathrm{~h}$ to TCS at concentrations that can be found in the environment $\left(27-37 \mu \mathrm{g} \mathrm{L}{ }^{-1}\right)$. In this freshwater microalga, TCS induced different toxic symptoms, at different cell levels, such as loss of algal proliferation capacity, modification of morphology (increase of biovolume and shape modification) and metabolism, namely, increase of intracellular ROS, decrease of photosynthetic pigments, GSH and CAR content and reduction of metabolic and photosynthetic activity. On the contrary of bacteria (target organism) the toxic mode of action of TCS over $P$. subcapitata, instead of a specific target, addressed multiple target sites.

\section{Funding support}

This study was supported by the Portuguese Foundation for Science and Technology (FCT) under the scope of the strategic funding of UID/ BIO/04469/2020 unit and BioTecNorte operation (NORTE-01-0145FEDER-000004) funded by the European Regional Development Fund under the scope of Norte2020 - Programa Operacional Regional do Norte.

\section{CRediT authorship contribution statement}

Manuela D. Machado: Conceptualization, Validation, Formal analysis, Investigation, Writing - original draft, Visualization. Eduardo V. Soares: Conceptualization, Validation, Writing - review \& editing, Visualization, Supervision.

\section{Declaration of Competing Interest}

The authors declare no conflict of interest.

\section{Appendix A. Supplementary data}

Supplementary material related to this article can be found, in the online version, at doi:https://doi.org/10.1016/j.aquatox.2020.105706.

\section{References}

Almeida, A.C., Gomes, T., Langford, K., Thomas, K.V., Tollefsen, K.E., 2017. Oxidative stress in the algae Chlamydomonas reinhardtii exposed to biocides. Aquat. Toxicol. 189, 50-59. https://doi.org/10.1016/j.aquatox.2017.05.014.

Beale, S.I., Appleman, D., 1971. Chlorophyll Synthesis in Chlorella. Plant Physiol. 47, 230-235. https://doi.org/10.1104/pp.47.2.230.

Bedoux, G., Roig, B., Thomas, O., Dupont, V., Le Bot, B., 2012. Occurrence and toxicity of antimicrobial triclosan and by-products in the environment. Environ. Sci. Pollut. Res. Int. 19, 1044-1065. https://doi.org/10.1007/s11356-011-0632-z.

Chen, X., Zhong, Z., Xu, Z., Chen, L., Wang, Y., 2010. 2' , $^{\prime}$-Dichlorodihydrofluorescein as a fluorescent probe for reactive oxygen species measurement: forty years of application and controversy. Free Radic. Res. 44, 587-604. https://doi.org/ 10.3109/10715761003709802.

Ciniglia, C., Cascone, C., Lo, Giudice R., Pinto, G., Pollio, A., 2005. Application of methods for assessing the geno- and cytotoxicity of triclosan to C. ehrenbergii. J. Hazard. Mater. 122, 227-232. https://doi.org/10.1016/j.jhazmat.2005.03.002.

Dann, A.B., Hontela, A., 2011. Triclosan: environmental exposure, toxicity and mechanisms of action. J. Appl. Toxicol. 31, 285-311. https://doi.org/10.1002/ jat.1660.

Del Río, L.A., López-Huertas, E., 2016. ROS generation in peroxisomes and its role in cell signaling. Plant Cell Physiol. 57, 1364-1376. https://doi.org/10.1093/pcp/pcw076.

Dhillon, G.S., Kaur, S., Pulicharla, R., Brar, S.K., Cledón, M., Verma, M., Surampalli, R.Y., 2015. Triclosan: current status, occurrence, environmental risks and 
bioaccumulation potential. Int. J. Environ. Res. Public Health 12, 5657-5684. https://doi.org/10.3390/ijerph120505657.

European Comission, 2014. Commission Regulation (EU) No 358/2014 of 9 April 2014 Amending Annexes II and V to Regulation (EC) No 1223/2009 of the European Parliament and of the Council on Cosmetic Products (parabens \& triclosan), European Union.

European Comission, 2016. Commission Implementing Decision (EU) 2016/110 of 27 January 2016 Not Approving Triclosan as an Existing Active Substance for Use in Biocidal Products for Product Type 1. European Union.

Fukami, T., Yokoi, T., 2012. The emerging role of human esterases. Drug Metab. Pharmacokinet. 27, 466-477. https://doi.org/10.2133/dmpk.dmpk-12-rv-042.

Gálová, E., Šalgovičová, I., Demko, V., Mikulová, K., Ševčovičová, A., Slováková, L., Kyselá, V., Hudák, J., 2008. A short overview of chlorophyll biosynthesis in algae. Biologia (Bratisl) 63, 947-951. https://doi.org/10.2478/s11756-008-0147-3.

González-Pleiter, M., Rioboo, C., Reguera, M., Abreu, I., Leganés, F., Cid, A., FernándezPiñas, F., 2017. Calcium mediates the cellular response of Chlamydomonas reinhardtii to the emerging aquatic pollutant triclosan. Aquat. Toxicol. 186, 50-66. https://doi. org/10.1016/j.aquatox.2017.02.021.

Haugland, R.P., 2005. Assays for cell viability, proliferation and function. In: Spence, M. T.Z. (Ed.), The Handbook- a Guide to Fluorescent Probes and Labeling Technologies, 10th edn. Invitrogen Corp, Eugene, pp. 699-776.

ISO, 2012. Water Quality -Fresh Water Algal Growth Inhibition Test with Unicellular Green Algae International Organization for Standardization. ISO Standard 8692. Geneva, Switzerland.

Jochem, F.J., 2000. Probing the physiological state of phytoplankton at the single-cell level. Sci. Mar. 64, 183-195. https://doi.org/10.3989/scimar.2000.64n2183.

Kumar, K.S., Dahms, H.-U., Lee, J.S., Kim, H.C., Lee, W.C., Shin, K.-H., 2014. Algal photosynthetic responses to toxic metals and herbicides assessed by chlorophylll $a$ fluorescence. Ecotoxicol. Environ. Saf. 104, 51-71. https://doi.org/10.1016/j. ecoenv. 2014.01.042.

Lesser, M.P., 2006. Oxidative stress in marine environments: biochemistry and physiological ecology. Annu. Rev. Physiol. 68, 253-278. https://doi.org/10.1146/ annurev.physiol.68.040104.110001.

Liang, X., Nie, X., Ying, G., An, T., Li, K., 2013. Assessment of toxic effects of triclosan on the swordtail fish (Xiphophorus helleri) by a multi-biomarker approach. Chemosphere 90, 1281-1288. https://doi.org/10.1016/j.chemosphere.2012.09.087.

Machado, M.D., Soares, E.V., 2012a. Development of a short-term assay based on the evaluation of the plasma membrane integrity of the alga Pseudokirchneriella subcapitata. Appl. Microbiol. Biotechnol. 95, 1035-1042. https://doi.org/10.1007/ s00253-012-4185-y.

Machado, M.D., Soares, E.V., 2012b. Assessment of cellular reduced glutathione content in Pseudokirchneriella subcapitata using monochlorobimane. J. Appl. Phycol. 24 https://doi.org/10.1007/s10811-012-9811-7.

Machado, M.D., Soares, E.V., 2013. Optimization of a microplate-based assay to assess esterase activity in the alga Pseudokirchneriella subcapitata. Water Air Soil Pollut. 224, 1358. https://doi.org/10.1007/s11270-012-1358-3.

Machado, M.D., Soares, E.V., 2014. Modification of cell volume and proliferative capacity of Pseudokirchneriella subcapitata cells exposed to metal stress. Aquat. Toxicol. 147, 1-6. https://doi.org/10.1016/j.aquatox.2013.11.017.

Machado, M.D., Soares, E.V., 2016. Short- and long-term exposure to heavy metals induced oxidative stress response in Pseudokirchneriella subcapitata. Clean Soil Air Water 44. https://doi.org/10.1002/clen.201600020.

Machado, M.D., Soares, E.V., 2019. Sensitivity of freshwater and marine green algae to three compounds of emerging concern. J. Appl. Phycol. https://doi.org/10.1007/ s10811-018-1511-5.

Machado, M.D., Soares, E.V., 2020. Reproductive cycle progression arrest and modification of cell morphology (shape and biovolume) in the alga Pseudokirchneriella subcapitata exposed to metolachlor. Aquat. Toxicol. 222, 105449 https://doi.org/10.1016/j.aquatox.2020.105449.

Machado, M.D., Lopes, A.R., Soares, E.V., 2015. Responses of the alga Pseudokirchneriella subcapitata to long-term exposure to metal stress. J. Hazard. Mater. 296, 82-92. https://doi.org/10.1016/j.jhazmat.2015.04.22.

Macri, D., 2017. Worldwide use of triclosan: Can dentistry do without this antimicrobial? Contemp. Clin. Dent. 8, 7-8. https://doi.org/10.4103/ccd.ccd 22517.

Mallick, N., Mohn, F.H., 2000. Reactive oxygen species: response of algal cells. J. Plant Physiol. 157, 183-193. https://doi.org/10.1016/S0176-1617(00)80189-3.

Maxwell, K., Johnson, G.N., 2000. Chlorophyll fluorescence - a practical guide. J. Exp. Bot. 51, 659-668. https://doi.org/10.1093/jexbot/51.345.659.

Mittler, R., Vanderauwera, S., Gollery, M., Van Breusegem, F., 2004. Reactive oxygen gene network of plants. Trends Plant Sci. 9, 490-498. https://doi.org/10.1016/j. tplants.2004.08.009.

Montaseri, H., Forbes, P.B.C., 2016. A review of monitoring methods for triclosan and its occurrence in aquatic environments. TrAC Trends Anal Chem. 85, 221-231. https:// doi.org/10.1016/j.trac.2016.09.010.

Murchie, E.H., Lawson, T., 2013. Chlorophyll fluorescence analysis: a guide to good practice and undersatnding some new applications. J. Exp. Bot. 64, 3983-3998. https://doi.org/10.1093/jxb/ert208.

Nag, S.K., Das, Sarkar S., Manna, S.K., 2018. Triclosan - an antibacterial compound in water, sediment and fish of River Gomti, India. Int. J. Environ. Health Res. 28 461-470. https://doi.org/10.1080/09603123.2018.1487044.
OECD, 2011. Test No. 201: Freshwater Alga and Cyanobacteria, Growth Inhibition Test. Organization for Economic Cooperation and Development. OECD Guidelines for Testing of Chemicals, Section 2. OECD Publishing Service, Paris, France. https://doi. org/10.1787/9789264069923-en.

Orvos, D.R., Versteeg, D.J., Inauen, J., Capdevielle, M., Rothenstein, A., Cunningham, V., 2002. Aquatic toxicity of triclosan. Environ. Toxicol. Chem. 21, 1338-1349. https:// doi.org/10.1002/etc.5620210703.

Pan, C.-G., Peng, F.-J., Shi, W.-J., Hu, L.-X., Wei, X.-D., Ying, G.-G., 2018. Triclosaninduced transcriptional and biochemical alterations in the freshwater green algae Chlamydomonas reinhardtii. Ecotoxicol. Environ. Saf. 148, 393-401. https://doi.org/ 10.1016/j.ecoenv.2017.10.011.

Paul, T., Kumar, S., Shukla, S.P., Pal, P., Kumar, K., Poojary, N., Biswal, A., Mishra, A., 2020. A multi-biomarker approach using integrated biomarker response to assess the effect of pH on triclosan toxicity in Pangasianodon hypophthalmus (Sauvage, 1878). Environ. Pollut. 260, 114001 https://doi.org/10.1016/j.envpol.2020.114001.

Phan, T.-N., Marquis, R.E., 2006. Triclosan inhibition of membrane enzymes and glycolysis of Streptococcus mutans in suspensions and biofilms. Can. J. Microbiol. 52, 977-983. https://doi.org/10.1139/w06-055.

Pinto, E., Sigaud-kutner, T.C.S., Leitão, M.A.S., Okamoto, O.K., Morse, D., Colepicolo, P., 2003. Heavy metal- induced oxidative stress in algae1. J. Phycol. 39, 1008-1018. https://doi.org/10.1111/j.0022-3646.2003.02-193.x.

Regel, R.H., Ferris, J.M., Ganf, G.G., Brookes, J.D., 2002. Algal esterase activity as a biomeasure of environmental degradation in a freshwater creek. Aquat. Toxicol. 59, 209-223. https://doi.org/10.1016/S0166-445X(01)00254-5.

Rowett, C.J., Hutchinson, T.H., Comber, S.D.W., 2016. The impact of natural and anthropogenic dissolved organic carbon (DOC), and $\mathrm{pH}$ on the toxicity of triclosan to the crustacean Gammarus pulex (L.). Sci. Total Environ. 565, 222-231. https://doi. org/10.1016/j.scitotenv.2016.04.170.

SCCS, 2010. Opinion on Triclosan-Antimicrobial Resistance. Luxembourg. Scientific Committee on Consumer Safety. Directorate-General Health \& Consumer. European Commission.

Soto, P., Gaete, H., Eliana Hidalgo, M., 2011. Assessment of catalase activity, lipid peroxidation, chlorophyll-a, and growth rate in the freshwater green algae Pseudokirchneriella subcapitata exposed to copper and zinc. Lat. Am. J. Aquat. Res. 39, 280-285. https://doi.org/10.3856/vol39-issue2-fulltext-9.

Stark, G., 2005. Functional consequences of oxidative membrane damage. J. Membr. Biol. 205, 1-16. https://doi.org/10.1007/s00232-005-0753-8.

Strickland, J., Parsons, T.R., 1972. A Practical Handbook of Seawater Analysis., second edi. Fisheries Research Board of Canada, Ottawa.

Suzuki, S., Yamaguchi, H., Nakajima, N., Kawachi, M., 2018. Raphidocelis subcapitata (=Pseudokirchneriella subcapitata) provides an insight into genome evolution and environmental adaptations in the Sphaeropleales. Sci. Rep. 8, 8058. https://doi.org/ 10.1038/s41598-018-26331-6.

Tarpey, M.M., Wink, D.A., Grisham, M.B., 2004. Methods for detection of reactive metabolites of oxygen and nitrogen: in vitro and in vivo considerations. AM J. Physiol. Regul. Integr. Comp. Physiol. 286, R431-R444. https://doi.org/10.1152/ ajpregu.00361.2003.

US-EPA, 2012. Algal Toxicity (OCSPP 850.4500). Ecological Effects Test Guidelines. Llution Prevention. United States Environmental Protection Agency, Washington, DC. EPA 712-C-006.

US-FDA, 2017. Safety and Effectiveness of Health Care Antiseptics; Topical Antimicrobial Drug Products for Over-the-Counter Human Use. Final rule. Food and Drug Administration. USA.

Wang, X.D., Lu, Y.C., Xiong, X.H., Yuan, Y., Lu, L.X., Liu, Y.J., Mao, J.H., Xiao, W.W., 2020. Toxicological responses, bioaccumulation, and metabolic fate of triclosan in Chlamydomonas reinhardtii. Environ. Sci. Pollut. Res. Int. 27, 11246-11259. https:// doi.org/10.1007/s11356-020-07704-9.

Xin, X., Huang, G., Liu, X., An, C., Yao, Y., Weger, H., Zhang, P., Chen, X., 2017. Molecular toxicity of triclosan and carbamazepine to green algae Chlorococcum sp.: A single cell view using synchrotron-based Fourier transform infrared spectromicroscopy. Environ. Pollut. 226, 12-20. https://doi.org/10.1016/j. envpol.2017.04.007.

Xin, X., Huang, G., An, C., Raina-Fulton, R., Weger, H., 2019a. Insights into long-term toxicity of triclosan to freshwater green algae in Lake Erie. Environ. Sci. Technol. 53, 2189-2198. https://doi.org/10.1021/acs.est.9b00259.

Xin, X., Huang, G., An, C., Feng, R., 2019b. Interactive toxicity of triclosan and nano$\mathrm{TiO} 2$ to green alga Eremosphaera viridis in Lake Erie: a new perspective based on Fourier Transform Infrared spectromicroscopy and synchrotron-based X-ray fluorescence imaging. Environ. Sci. Technol. 53, 9884-9894. https://doi.org/ 10.1021/acs.est.9b03117.

Yang, L.-H., Ying, G.-G., Su, H.-C., Stauber, J.L., Adams, M.S., Binet, M.T., 2008. Growthinhibiting effects of 12 antibacterial agents and their mixtures on the freshwater microalga Pseudokirchneriella subcapitata. Environ. Toxicol. Chem. 27, 1201-1208. https://doi.org/10.1897/07-471.1.

Zheng, M., Liang, K., Wang, B., x, Sun, Yue, Y., Wan, W., Zheng, L., 2013. Isolation and characterization of an enoyl-acyl carrier protein reductase gene from microalga Isochrysis galbana. Chin. J. Oceanol. Limnol. 31, 398-406. https://doi.org/10.1007/ s00343-013-2168-1. 